\title{
Necrotizing mastitis caused by Staphylococcus aureus in goat. Case report
}

Mastite necrosante causada por Staphylococcus aureus em cabra. Relato de caso

\section{Carolina Nogueira de Moraes ${ }^{1 *}$, Leandro Maia ${ }^{1}$, Luana de Cássia Bicudo ${ }^{1}$; Sony Dimas Bicudo ${ }^{1}$}

${ }^{1}$ São Paulo State University - UNESP, Rubião Júnior s/n, CEP: 18618-970, Botucatu, São Paulo, Brazil.

\begin{abstract}
It is reported a case of necrotizing mastitis by Staphylococcus aureus in goat whose signs were right ceiling with alteration on coloration, tenderness, consistency and bloody discharge. Supportive treatment with parenteral fluid therapy and antibiotics were performed prior to surgery to remove the affected hemigland. Additionally, postoperative topical therapy with hydrogen peroxide, tincture of iodine $2 \%$ and copper sulfate was conducted at different times. The treatment applied and the emergency care of the animal in this case were effective for improvement of the clinical case and were extremely important to maintaining the animal's life.
\end{abstract}

Key-words: mastitis, goat, copper sulfate

Resuno. Relata-se um caso mastite necrosante por Staphylococcus aureus, em cabra cujos sinais eram teto direito com alteração na coloração, sensibilidade, consistência e secreção sanguinolenta. $\mathrm{O}$ tratamento de suporte com fluidoterapia parenteral e antibioticoterapia foi feito previamente à intervenção cirúrgica para remoção da hemiglândula acometida. Adicionalmente, foi realizada a terapia tópica pós-cirúrgica com água oxigenada, tintura de iodo $2 \%$ e sulfato de cobre em diferentes momentos. O tratamento aplicado e o pronto atendimento do animal no caso em questão mostraram-se eficientes para a resolução do caso clínico e foram de extrema importância para manutenção da vida do animal.

Palavras-chave: mastite, cabra, sulfato de cobre

*Corresponding Author. *_carolnmoraes@ hotmail.com

Recebido em 3.2.2016. Aceito 10.6.2016

http://dx.doi.org/10.5935/1981-2965.20160025 


\section{Introduction}

Goat husbandry's improvement is accompanied by an increase in milk production due to the high energy value of this milk's species. This has required the consideration of the milk's quality, especially in relation to factors that alter your sanity and composition, such as mastitis (TONIN, 1999).

Mastitis is defined as the inflammation of the mammary gland, can be of fungal, viral or bacterial etiology and promote physical, chemical and usually bacteriological alterations in the milk (SHEARER AND HARRIS, 2003; MAVROGIANNI et al. 2011).

Can be classified into subclinical and clinical with acute, chronic or necrotizing evolution. In view of necrotizing mastitis, the main bacteria involved is Staphylococcus sp. which can be associated or not with Clostridium perfringens (Tyler; Cullor, 2002) or, more rarely, to Escherichia coli., as reported by RIBEIRO et al. (2007). Studies have been developed in view of applicable techniques to the use of physiologic mastectomy, radical or partial mastectomy of the mammary gland in search of the most appropriate methods to treat necrotizing mastitis in goats (BURGUS et al., 2008; ALLEN et al., 2008; QUEIROZ et al.,
2009). Based on the above, the objective is to report a case of necrotizing mastitis by Staphylococcus aureus in goats, as well as describe their treatment and evolution.

\section{Case Report}

A Boer goat, five years old, weighing $60 \mathrm{~kg}$ was referred to the Veterinary Hospital of FMVZ (UNESPBotucatu) with alteration in the appearance and secretion of the right mammary gland. On physical examination, the animal was weak, with paresis, congested ocular mucosa, tachycardia (140 bpm), tachypnea (40mpm), dyspnea and normothermia $\left(39.3^{\circ} \mathrm{C}\right)$.

At inspection of the mammary gland, it was found normality of left glandular tissue and ceiling for consistency, sensitivity, staining and milk secretion.

However, the right ceiling and half of this udder showed limited areas of bluish/ black, cold to touch, without soreness, with firm consistency on palpation and presence of bloody discharge. Based on the clinical signs presented, the presumptive diagnosis was necrotizing mastitis.

This way, a sample of the bloody discharge from the right ceiling was aseptically collected and forwarded to the Department of Microbiology of FMVZ for the realization of bacteriological culture 
and antibiogram in which it was evident the growth of Staphylococcus aureus.

The immediate support treatment with parenteral hydration with saline solution $0.9 \%$ and broad-spectrum antibiotics (trimetopin and sulfadoxine, 30 $\mathrm{mg} / \mathrm{kg}$, once day, intramuscular, 6 days) was done.

After, it was performed the partial mastectomy of the affected hemigland after disinfection with chlorhexidine degerming 2\%. The partial debridement was performed through a circular incision in the affected area, with the assistence of a cable scalpel, to remove all portion of the mammary gland that appeared necrotic, trying to leave only the healthy tissue. There was no suture to approach or closure of the incision, in order to permit the drainage of content and healing by second intention. This procedure was repeated in the following day to remove the remainder of necrotic tissue.

After debridement, topical treatment was done twice a day for embrocation with hydrogen peroxide and tincture of iodine $2 \%$ for 10 days, until partial tissue organization. Then the topic treatment was done with saturated aqueous copper sulfate and hydrogen peroxide for 10 days, thereafter returning to topical treatment instituted initially, with hydrogen peroxide and tincture of iodine $2 \%$, until the resolution of the process.
After one month of hospitalization and topical treatment, there was an evident improvement in the resolution of wound, healing by secondary intention and scar retraction.

\section{Discussion}

Clinical stabilization of the animal and prevention of endotoxic shock are associated with immediate support treatment, in which can be done the use of antibiotics and hydration (AMRASINGHE et al., 2009). Such adopted approach also resulted in clinical improvement of the animal, stabilizing and preventing the advancement of the clinical signs in view of the highly pathogenic bacteria involved.

As found by Burgos et al. (2008), the isolated agent was the bacteria belonging to the genus Staphylococcus $s p$ and specifically in this case the Staphylococcus aureus, which can be found on ceiling ends and/or ceiling lesions and is able to cause subclinical and necrotizing mastitis (AMRASINGHE et al., 2009). The last one occurs due to release of toxins by the bacteria which causes the formation of abscesses and cellular destruction (PETERSSONWOLFE et al., 2010).

Partial mastectomy of the affected hemigland was performed in order to remove the infected necrotic tissue, contributing to the overall improvement of the animal and to possibility the 
maintenance of milk production in the other mammary gland. These results agree with those obtained by BURGOS et al. (2008).

In this case, partial mastectomy with clinical treatment allowed good results. In the literature it is reported that radical mastectomy (Queiroz et al., 2009), binding of pudendal vessels (Amrasinghe et al., 2009) and physiologic mastectomy (Allen et al., 2008) are presented as alternative and beneficial since they eliminate the affected and damaged tissue, reducing the release of toxins.

Topical treatment conducted with hydrogen peroxide, tincture of iodine $2 \%$ and saturated aqueous copper sulfate at different times proved to be effective in healing the wound, not being evidenced complications during the treatment.

Topical use of copper sulfate is a viable approach to provide healing by second intention in dermal wounds. That is because according to revision submitted by Borkow et al. (2010), copper participates in the synthesis and stabilization of extracellular matrix proteins of the skin and stimulates angiogenesis due their potential for expression of vascular endothelial growth factor. It is noteworthy that during the inspection and palpation of the mammary gland no foreign body was identified, and thus there is strongly indicative of contamination by ascending pathway, as already has been reported in the literature by RIBEIRO et al. (2007).

Ceiling contamination by the isolated genus (Staphylococcus sp) can occur through milkers' hands, washcloths, teat cup liners, and flies (Petersson-Wolfe, et al. 1998).

According to Cullor and Tyler (2002), hygiene during milking is seen as a way to control the dissemination of the disease once the antibiotics alone does not eliminate the problem in the herd.

Alternatively, there are available commercially vaccines against clinical gangrenous mastitis that, according to Contreras et al. (2007), can be used in small ruminant herds in which the disease has high incidence.

\section{Conclusion}

The treatment with parenteral hydration, antibiotics, topical treatment and partial mastectomy was considered effective for the treatment and control of mastitis necrotizing in this present case. Such success was comproved by the improvement of the clinic case and recovery within one month.

However, the success in the survival and recovery of milk production by the not affected hemigland depends not only of the pathogenicity of the isolated microorganisms from the mammary gland but also from the therapeutic procedures readily adopted. 
Preventive procedure is the primordial to avoid this type of affection, contributing to increased survival and decreased spending on medicines, replacement and discard of animals.

\section{REFERENCES}

1.ALLEN, A.J.; BARRIGTON, G.M.; PARISH, S.M. Physiologic mastectomy via flank laparotomy. Veterinary Clinics of North America: Food animal Practice, v.24, n.3, p.511-516, 2008.

2. AMARASINGHE, A.A.A.W.K.; GUNARATHNAM, I.; PERERA, G.D.R.K.; PUSPAKUMARA, P.G.A. An alternative treatment approach for gangrenous mastitis in dairy goats: a case report. IN: Proceedings of the Peradeniya University Research Sessions, 14., 2009, Sri Lanka. Anais...Sri Lanka: 2009. p. 54-56.

3. BURGOS, F.R.N.F.; ALMEIDA, E.L.; MORAIS, F.N.M.; WANDERLEY, E.K.; RABELO, S.S.A.; MELO, M.T. Mastectomias parciais em cabras com mastite gangrenosa unilateral diagnosticadas na clínica de grandes animais da Universidade Federal Rural de Pernambuco (UFRPE). Ciência Veterinária nos Trópicos, v. 11, n.1, p. 30 - 35, 2008.

4. BORKOW, G.; GABBY, J.; DARDIK, R.; EIDELMAN, A.L.; LAVIE, Y.; GRUNFIELD, Y.; IKHER. S.; HUSZAR, M.; ZATCOFF, R.C.; MARIKOVSKY, M. Molecular mechanisms of enhanced wound healing by copper oxide-impregnated dressings. Wound Repair Regeneration, v.18, n.2, p. 266-275, 2010.

5. CONTRERAS, A.; SIERRA, D.; SÁNCHEZ, A.; CORRELES, J.C.; MARCO, J.C.; PAAPE, M.J.; GONZALOS, C. Mastitis in small ruminants. Small Ruminant Research, v.68, n.1-2, p. 45-153, 2007.

6. MAVROGIANNI, V.S.; MENZIES,P.I.; FRAGKOU, I.A.; FTHENAKIS,G.C. Principles of mastitis treatment in sheep and goats. Veterinary Clinics of North America: Food animal Practice, v. 27, n.1, p. 115-120, 2011.

7. PETERSSON-WOLFE, C.S.; MULLARKY, I.K.; JONES, G.M. Staphylococcus aureus mastitis: cause, detection, and control. Virginia Cooporative Extention, p.1-7, 2010.

8. QUEIROZ, R.A.; ALMEIDA, E.L.; BURGOS, F.R.N.F.; NASCIMENTO, H.B.; SIQUEIRA FILHO, R.S.; RIBEIRO, J.J.S.; SILVA, E.R.R.. Mastectomia radical em cabra. IN: Brasil: IX jornada de ensino, pesquisa e extensão - semana nacional de ciência e tecnologia, 2009. Available in: http://www.researchgate.net/publication/22850 0023_MASTECTOMIA_RADICAL_EM_CA BRA. Accessed in 02-2013.

9. RIBEIRO, M.G.; LARA, G.H.N.; BICUDO, S.D.; SOUZA, A.V.G.; SALERNO, T.; SIQUEIRA, A.K..; GERALDO, J.S. An unusual gangrenous goat mastitis caused by Staphylococcus aureus, Clostridium perfringens and Escherichia coli co-infection. Arquivo Brasileiro de Medicina Veterinária e Zootecnia., v.59, n.3, p.810-812, 2007.

10. SHEARER, J.K.; JR HARRIS, B. Mastitis in dairy goats. Florida: University of Florida IFAS Extension, 2003. Available in: http://www.georgiagoat.com/articles/Masti tis.pdf . Accessed in 02-2013.

11. TONIN, F.B. Aspectos da etiopatogenia e diagnóstico da mastite caprina. In: ENCONTRO DE PESQUISADORES EM MASTITE, 3., 1999, Botucatu. Anais... Botucatu: [s. n.] 1999. p.71-77.

TYLER, J.W.; CULLOR, J.S. Sanidade e Distúrbios da Glândula Mamária. IN: SMITH, B. P. Tratado de medicina interna de grandes animais. Brasil: MANOLE, 2002. p.1019-1038. 